\title{
Modelling Mode Choice at Sharjah University City, United Arab Emirates
}

\author{
Lubna Obaid ${ }^{1, a}$ and Khaled Hamad ${ }^{1}$ \\ ${ }^{1}$ Department of Civil and Environmental Engineering, University of Sharjah, Sharjah, U.A.E.
}

\begin{abstract}
A growing interest in the behaviour of travelers to university campuses has recently emerged whether by university administrators or transport officials. Understanding the modal choice determinants of university travellers increases the opportunity for finding appropriate policies and solutions to reduce traffic congestion and parking needs as well as to encourage active transportation hence achieving more sustainable mobility. This research study investigates the differences in mode choice habits among the various groups of travellers to Sharjah University City (SUC) in the United Arab Emirates (UAE), including students, staff, faculty, and university visitors. A revealed preference survey was distributed randomly throughout SUC. Using information collected from this survey, multinomial discrete logit choice models were developed to evaluate the SUC travellers' mode-choice likelihood for the following modes: car, private bus, public bus, taxi, and active transport (walking and biking). It was found that travel time, travel distance, trip makers' characteristics (gender, citizenship, car ownership, car sharing, and the number of cars per household), and other contributing factors ( Weathers conditions, Infrastructure adequacy, and bus services quality) are the main factors that affect significantly the mode choice at SUC. Further, a sensitivity analysis was conducted to study how the considered factors influence the mode choice. The developed model can be used in future studies to predict travel demand at SUC in response to new policies and solutions set by university administrators or transport officials.
\end{abstract}

\section{Introduction}

Many university campuses worldwide experience increasing travel demands leading to excessive traffic congestion and parking shortage. University campuses have complex, unique travel and usually characterized by their pro-active environment [1]. To solve transport problems at their university campuses, various researchers have studied this problem in recent years to understand university travelers' characteristics, travel patterns, and modal choice factors. Understanding the travel behavior of university travelers, and specifically their dependence on the private auto for commuting, can help universities and other stakeholders work together toward improvements to policies, programs, and infrastructure that encourage students' use of public transport or non-motorized modes of travel [2]. This is critical particularly in the case of large universities since student travel behavior directly impacts congestion levels in adjacent streets, the well-being of students and staff, as well as that of residents and businesses in the university neighborhood.

Like many other university campuses around the world, Sharjah University City (SUC) — which is the tertiary-education district in the City of Sharjah, United Arab Emirates) - suffers from severe traffic congestion on daily basis. With the difficulty of expanding the existing roadway network's capacity, the interest of the SUC's multi-stakeholders has turned into exploring any kind of transportation system, policy, or technique that reduces vehicular traffic. Towards this, a research project was awarded to develop a travel demand forecasting model to help plan for future sustainable transport improvements and policies at SUC.

The study's goal is to investigate SUC travelers' mode choice. Towards achieving this goal, the following four objectives were set: (1) collect socio-demographic and trip data using an online-survey containing both qualitative and quantitative questions, (2) develop discrete mode choice models, namely multinomial logit models (MNL), to investigate statistically the factors that are most likely to influence drivers utility and likelihood for choosing a specific transportation mode over other alternative modes and replicates the SUC travelers mode choice behavior, (3) conduct a sensitivity analysis to review the influence of multiple factors on travelers mode choice patterns, and (4) suggest solutions to encourage active and public transportation modes. While this paper focuses on SUC, it still sets an example of how universities can analyze the students' modal choice determinants to address their sustainability goals. Further, the study contributes to the emerging literature on understanding student behavior at university campuses in the region and worldwide.

${ }^{a}$ Corresponding author: lobaid@sharjah.ac.ae 


\section{Previous studies}

Mode choice at university campuses has been an active research area for over two decades now.

Delmelle \& Delmelle explored the spatial, temporal, and gender differences in transportation commuters mode choice within Idaho University students [3]. The main finding of this research is that male students are more likely to switch their driving mode through the year whereas female students are more to keep using cars. Also, noticeable commuters' preferences were found between graduate and undergraduate students.

Longo et al conducted a study to analyze mobility issues at the campus of an Italian university [4]. A webbased survey was carried out to identify solutions to reduce traffic congestion and improve accessibility to their campus. The survey participants were mostly residents and commuters and prefer to travel using public transportation as busses or trams. The Analytical Hierarchy Process was applied to prioritize these solutions from the perspectives of different user groups. The prioritizing criteria included several factors as travel time, cost, comfort, safety, flexibility, and environment.

Shannon et al assessed the commuting habits of students and staff at an Australian university campus [2]. The results of an online survey highlighted the transport modes being used, factors affecting transport decisions, and the potential for changing the transit mode. The survey results indicated that around $20 \%$ of the staff and $46 \%$ of the students used active modes of transport such as walking, cycling, and transit. Furthermore, potentially $30 \%$ of staff and students would like to switch to active transport modes; therefore, the study suggested reducing barriers to achieving this shift. Suggested polices include implementation of a subsidized public transport pass, increased student housing on or near campus, increased the cost of parking, and improved bus services and cycle networks.

Miralles-Guasch studied the transport patterns at the Autonomous University of Barcelona, including motivations, barriers and user preferences, and explores the main transport challenges faced by the their campus [5]. Over 5500 members of the university community were surveyed and results showed that the primary challenges of switching from private to public transportation are the lack of adequate infrastructure, the marginal role of walking and cycling as means of transportation, and the longer trip time when using public transportation.

Balsas explored how college campuses have encouraged a modal shift from cars to bicycling and walking [6]. The purpose of the study was to identify some of the best practices undertaken by several universities to make their campuses more sustainable communities for bicyclists and pedestrians. A survey of eight bicycle and pedestrian friendly campuses across the USA was conducted. A key finding of the survey was that college campuses are de-marketing automobile commuting and promoting alternative transportation modes. A final recommendation of the research was to promote the shift from private to public transportation through universities since they are a proactive educational environment.

Abubakar et al. explored students' perspectives towards the sustainability of their campus based on a survey of 152 students of the College of Architecture and Planning at the University of Dammam in the Kingdom of Saudi Arabia [7]. The study results indicated that students showed a great deal of awareness and concern about campus environmental sustainability; nevertheless, they lacked interest and willingness to participate in initiatives towards achieving sustainability. An interesting point found in this study is that transportation initiatives were fewer compared to sustainable landscaping and waste conservation. Their research concluded by highlighting the importance of incorporating sustainability into campus travel operations and training university students in promoting environmental sustainability in the KSA and the MENA region.

Aoun et al. conducted a study at the American University of Beirut (AUB) in Lebanon to explore potential practices for better sustainable transportation practices at AUB [8]. Given the high-income population and high car-ownership at AUB, conventional strategies might not be effective. Their main learned lessons from reviewing the experience of five American university campuses can be summarized as follow: First, campus transport services do not always stem from existing public transport services. Second, designing a campus transport service catered to the target population can be extremely effective with high-income clients. Finally, mass transport ridership is partly dependent on driving disincentives such as limited and priced parking. The study proposed to have a new dynamic mobility solution, i.e. dynamic taxi sharing. Their preliminary mode-shift survey demonstrated the potential market and possible positive reductions in-vehicle trips.

Villanueva et al measured pedometer steps for university students who used transit and passenger vehicles to travel to and from the campus of a University of Western Australia [9]. A field experiment over university students where about 100 undergraduate students wore a pedometer for five consecutive days and completed a travel activity diary. The results of the experiment were and then compared to motor vehicle users. The comparison indicated that public transport users made more steps daily compared to private vehicle users. The study recommended encouraging public transport use could help increase and maintain community physical activity levels.

Table 1 summarizes and compares several related research studies in terms of the statistical analysis used, the modes assessed, as well as the variables considered. As can be seen in Table 1, various statistical approaches 
were used to assess the general public modal choice behavior in many countries in the Middle East and North
Africa (MENA) region; yet only few studies focused on mode choice for university travelers [10].

Table 1: Summary of the variables applied in statistical models for university students

\begin{tabular}{|c|c|c|c|c|}
\hline Ref. & University & Modes & Models & Variables/Attributes \\
\hline$[11]$ & $\begin{array}{l}\text { Seven } \\
\text { campuses } \\
\text { in Greater } \\
\text { Toronto }\end{array}$ & $\begin{array}{l}\text { Active modes, } \\
\text { transit, Car as a } \\
\text { driver, and Car as } \\
\text { passenger }\end{array}$ & $\begin{array}{l}\text { Multinomial } \\
\text { logit models } \\
(\mathrm{MNL})\end{array}$ & $\begin{array}{l}\text { - Socio-economic: Gender, household size, number of } \\
\text { cars in H.H., building type, age, number of members } \\
\text { in the residence, income level. } \\
\text { - Travel cost: Trip distance, trip frequency. } \\
\text { - TDM: car sharing, transit pass ownership, bike } \\
\text { ownership. } \\
\text { - Residential self-selection factors: The primary factor } \\
\text { of house location is transit, walking, bike. } \\
\text { - Built environment: Density of pedestrian networks, } \\
\text { land use mix }\end{array}$ \\
\hline [12] & $\begin{array}{l}\text { University } \\
\text { of } \\
\text { Michigan }\end{array}$ & $\begin{array}{l}\text { Single occupant } \\
\text { vehicle (SOV), Car } \\
\text { pool, Walk, } \\
\text { Bicycle, and Bus }\end{array}$ & $\begin{array}{l}\text { Binary Logit } \\
\text { Model }\end{array}$ & $\begin{array}{l}\text { - Socio-economic: Gender, Occupation. } \\
\text { - Mode specific: } \\
\text { Bicycle: Adverse weather, bicycle theft, general crime, } \\
\text { lack of bicycle lanes, No bicycle, distance, lack of } \\
\text { interest. } \\
\text { Walking: Police presence, lighting, safe intersections, } \\
\text { traffic enforcement, emergency phones, fuel cost, } \\
\text { parking cost. }\end{array}$ \\
\hline$[3]$ & $\begin{array}{l}\text { Los } \\
\text { Angeles }\end{array}$ & $\begin{array}{l}\text { Transit (Bus), Bike, } \\
\text { Walk, Drive alone, } \\
\text { Carpool, and } \\
\text { Telecommuting }\end{array}$ & MNL & $\begin{array}{l}\text { - Trip makers': Gender, residence choice, age, } \\
\text { occupation. } \\
\text { - Trip: Travel time, time of travel, commute } \\
\text { distance. } \\
\text { - } \quad \text { Travel demand management: Parking permit. } \\
\text { - } \quad \text { Mode specific: Transit pass, direct bus lane. }\end{array}$ \\
\hline$[13]$ & $\begin{array}{l}\text { University } \\
\text { of Coimbra }\end{array}$ & $\begin{array}{l}\text { Car, and Public } \\
\text { transportation }\end{array}$ & MNL & $\begin{array}{l}\text { Occupation, income per capita, residence distance, } \\
\text { gender, Public transportation usage frequency in the } \\
\text { last month. }\end{array}$ \\
\hline$[14]$ & $\begin{array}{l}\text { North } \\
\text { Dakota } \\
\text { State } \\
\text { University }\end{array}$ & $\begin{array}{l}\text { Automobile, Bus, } \\
\text { Carpool, } \\
\text { motorcycle, Non- } \\
\text { motorized }\end{array}$ & MNL & $\begin{array}{l}\text { In-vehicle travel time (IVTT), out-of-vehicle travel } \\
\text { time (OVTT), Parking demand factor (PKD) }\end{array}$ \\
\hline$[15]$ & $\begin{array}{l}\text { University } \\
\text { of Texas at } \\
\text { El Paso }\end{array}$ & N.A. & MNL & $\begin{array}{l}\text { The distance of the parking facility i from the desired } \\
\text { destination zone of the driver, Distance of the parking } \\
\text { facility i from the current vehicle position of driver, } \\
\text { and Parking fee of the parking facility i. }\end{array}$ \\
\hline$[10]$ & $\begin{array}{l}\text { University } \\
\text { of Beirut }\end{array}$ & Car, Bus, and Jitney & $\begin{array}{l}\text { Nested Logit } \\
\text { model } \\
(\mathrm{NLM})\end{array}$ & $\begin{array}{l}\text { - For students: Cost, travel time, monthly H.H. income, } \\
\text { Gender, Number of cars per H.H. } \\
\text { - For general public: Cost, travel time, monthly H.H. } \\
\text { income, trip frequency per week }\end{array}$ \\
\hline$[16]$ & $\begin{array}{l}\text { University } \\
\text { of } \\
\text { Cantabria }\end{array}$ & $\begin{array}{l}\text { Parking within the } \\
\text { Campus, Park-and- } \\
\text { ride, Parking in the } \\
\text { surrounding area, } \\
\text { Bus, and Bike- } \\
\text { sharing }\end{array}$ & $\begin{array}{l}\text { Mixed logit } \\
\text { model }\end{array}$ & $\begin{array}{l}\text { Travel time, waiting time for the bus, time to find a } \\
\text { parking space, access time to the Campus from the } \\
\text { parking spot, Cost of parking the car or travelling by } \\
\text { bus or bike (in the case of the bike-sharing system) }\end{array}$ \\
\hline$[17]$ & $\begin{array}{l}\text { University } \\
\text { of Calabria }\end{array}$ & $\begin{array}{l}\text { Walk, and Electric } \\
\text { minibus }\end{array}$ & MNL & $\begin{array}{l}\text { Travel time (walking by foot/ transit), transit waiting } \\
\text { time, bus crowding, bus comfort, age, patience, } \\
\text { laziness }\end{array}$ \\
\hline [18] & $\begin{array}{l}\text { Istanbul } \\
\text { Technical } \\
\text { University }\end{array}$ & $\begin{array}{l}\text { Private car, Service } \\
\text { vehicle, and Public } \\
\text { transport }\end{array}$ & MNL & $\begin{array}{l}\text { Mode specific variables: } \\
\text { Private car: H.H. income, trip running cost, parking } \\
\text { fee. } \\
\text { Service vehicle: Age, vehicle time, OVTT. } \\
\text { Public transport: IVTT, OVTT, ticket fee. }\end{array}$ \\
\hline [19] & $\begin{array}{l}\text { McMaster } \\
\text { University, } \\
\text { Hamilton }\end{array}$ & $\begin{array}{l}\text { Car, Bicycle, Walk, } \\
\text { and Bus }\end{array}$ & MNL & $\begin{array}{l}\text { Street and sidewalk density, travel time, access time, } \\
\text { vehicle ownership, age, gender, living arrangements, } \\
\text { vehicle comfort, shelter, parking (TDM) }\end{array}$ \\
\hline
\end{tabular}




\section{Methods and materials}

\subsection{Study area}

Sharjah University City is the tertiary-education district in the City of Sharjah with a total area of over 1,500 hectares. Located southeast of the City of Sharjah's downtown (Figure 1), SUC has a beautifully crafted landscape and distinguished Islamic architecture for most of the buildings. It encompasses over 15 tertiary education and research institutions including: University of Sharjah (with its men, women, medical, and fine arts campuses), American University of Sharjah, Higher Colleges of Technology (with its both men and women campuses), the Arabic Language Academy in Sharjah, Al-Qasimia University, and Sharjah Police Academy. Over 20,000 students are enrolled in the various institutions inside SUC. These students are served by over 2,000 faculty and staff members. Out of these, around 6,000 students and faculty members live in the various dormitories and houses on their respective campuses.

\subsection{Data Collection}

A well-prepared questionnaire was distributed among travelers on campus, including students, faculty, staff, and visitors. A web-based platform was used for developing and administering the questionnaire. The survey asked participants to report their trips that had at least one end at SUC to obtain comprehensive information about the activity-travel patterns of the university population. In addition, the survey collected data on intra-campus trips where both trips ends are located on the same campus to fully measure all travel demand that occurs in and around the university campus. The survey was randomly distributed over SUC road commuters, and over 4000 responds were collected.

The questionnaire survey consisted of two sections focusing on:

- Demographic characteristics: Gender, nationality, status, vehicle ownership, etc.
- Commuting characteristics: Trip purpose, mode of travel, trip duration and length, origin and destination, etc.

Five transportation modes widely used by SUC travelers were assessed in this study: private car, taxis, private bus, public bus, and active transportation (i.e., walk and bike). For this research, three types of variables affecting mode choice were considered:

1. Trip makers' characteristics: Gender, citizenship, status, car ownership, and number of cars per household.

2. Trip characteristics: In-vehicle travel time (IVTT) in minutes, out-of-vehicle travel time (OVTT) in minutes, and trip distance in kilometers.

3. Other contributing factors: Car sharing, weather conditions, bus services, and status of transport infrastructure.

These variables were selected following previous studies. Only the trip duration is considered for active modes. The OVTT for cars and taxis was calculated using Eq. 1 whereas for public and private busses using Eq. 2.

$$
\begin{array}{r}
\text { OVTT for Car = Parking time } \\
+ \text { Walking time to destination }
\end{array}
$$

\subsection{Descriptive analysis of the selected variables}

Descriptive statistics of the selected variables are summarized in Table 2 and Table 3. Out of all the travelers who participated in the survey, $84 \%$ were university students while the remaining $16 \%$ were staff, faculty, and visitors. Around $55 \%$ of them were males. The majority (over 70\%) were expatriates while the remaining were UAE nationals. Almost two-thirds of the respondents $(66 \%)$ prefer to drive alone rather than car sharing and $64 \%$ owned their own cars. In contrast, a low percentage (almost 13\%) travel from and to the university with their colleagues/family members.

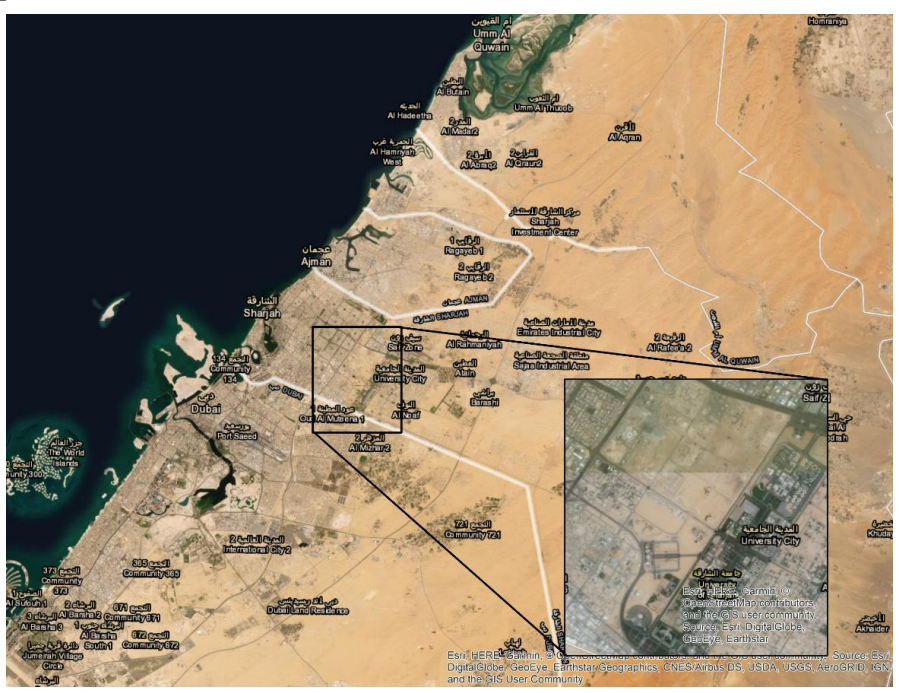

Figure 1: SUC campus location 
Table 2: Descriptive statistics of continuous variables

\begin{tabular}{cccccccc}
\hline & Variables & Mean & Median & Std. dev. & IQR & Min & Max \\
\hline Trip & IVTT $(\min )$ & 26.41 & 25 & 19.88 & 25 & 1.000 & 180 \\
\cline { 2 - 7 } related & OVTT $(\mathrm{min})$ & 16.14 & 15 & 11.61 & 17 & 0 & 45 \\
\cline { 2 - 7 } factors & 10.04 & 8.507 & 13.37 & 11.17 & 0.1 & 169 \\
\cline { 2 - 7 } & Trip distance $(\mathrm{km})$ & 10.17 &
\end{tabular}

Table 3: Descriptive statistics of categorical variables

\begin{tabular}{|c|c|c|c|}
\hline \multicolumn{4}{|c|}{$\mathrm{n}=4300$ respondents } \\
\hline & Variables & Code & $\%$ of total \\
\hline \multirow{12}{*}{$\begin{array}{l}\text { Trip maker's } \\
\text { characteristics }\end{array}$} & \multirow{2}{*}{ Gender } & Male & 56.21 \\
\hline & & Female & 43.8 \\
\hline & \multirow{2}{*}{ Citizenship } & Local & 25.8 \\
\hline & & Expatriate & 74.21 \\
\hline & \multirow{4}{*}{ Academic Standing } & Student & 84.13 \\
\hline & & Faculty & 6.64 \\
\hline & & Staff & 7.05 \\
\hline & & Visitor & 2.18 \\
\hline & \multirow{2}{*}{ Car Ownership } & Yes & 64.3 \\
\hline & & No & 35.7 \\
\hline & \multirow{2}{*}{ Number of Cars per Household } & One car or less & 6.85 \\
\hline & & Multiple cars & 93.15 \\
\hline \multirow{8}{*}{$\begin{array}{c}\text { Other } \\
\text { contributing } \\
\text { factors }\end{array}$} & \multirow{2}{*}{ Car Sharing } & Yes & 12.63 \\
\hline & & No & 66.44 \\
\hline & \multirow{2}{*}{ Inconvenient Bus service } & Yes & 34.7 \\
\hline & & No & 65.3 \\
\hline & \multirow{2}{*}{ Harsh Weather Conditions } & Yes & 38.78 \\
\hline & & No & 61.22 \\
\hline & \multirow{2}{*}{$\begin{array}{c}\text { Inadequate Sustainable Transportation } \\
\text { Infrastructure }\end{array}$} & Yes & 10.2 \\
\hline & & No & 89.8 \\
\hline
\end{tabular}

As for the other contributing factors, weather conditions had a slightly higher impact on the travelers' attitudes toward shifting for more sustainable transportation modes while the adequacy of sustainable transport infrastructure (sidewalks and bike lanes) had a minor impact.

Travelers' trips ranged from a minimum of $100 \mathrm{~m}$ for in campus trips to almost $170 \mathrm{~km}$ for out of campus intra emirates trips. Their in-vehicle trips' duration ranged from 1 to 180 minutes with an average of around 26 minutes, while the out-of-vehicle trip duration ranged from 0 minutes to 45 minutes with an average of 15 minutes.

\subsection{Modelling approach}

To help analyze the relationships between mode choice behavior of SUC travelers and its determinants a multinomial logit (MNL) model was developed using the aforementioned data collected. As shown in Table 1, the MNL approach has been widely used to model mode choice around the world. Basically, the probability the traveler $i$ would choose the mode of transport $j$ among the set of available modes $k$ is given by Eq.3.::

$$
P_{i j}=\operatorname{Pr}\left(U_{i j}>U_{i k}\right), \forall k \neq j
$$

where $k$ represents variable transportation means, and $U_{i k}$ is the maximum utility required for a traveler $i$ if the traveler chooses the mode $j$. The utility of traveler $i$ for choosing mode $j$ is given by Eq.4.:

$$
U_{i j}=\beta_{j} X_{i j}+\varepsilon_{i j}
$$

where $\beta_{j}$ is a vector of the unknown coefficients for each of the explanatory variables, $X_{i j}$ is the vector of the known variables, and $\varepsilon_{i j}$ is the random component of the utility. If the stochastic terms $\varepsilon_{i j}$ are assumed to be independent, the logit choice probability can be expressed as the following Eq.5.::

$$
P_{i j}=\frac{e^{\beta_{j} X_{i j}}}{\Gamma_{\sim} \beta_{i} X_{i i}}
$$

The widely used statistical package IBM SPSS Version 24 was utilized to estimate our model. It is also worth mentioning that the $\beta_{s}$ are estimated by maximizing a log likelihood function. 
Table 4:Multinomial logit model estimation results

\begin{tabular}{|c|c|c|c|c|c|c|}
\hline Variable & Cases (Case Code) & Car (1) & Taxi (2) & $\begin{array}{l}\text { Private } \\
\text { Bus (3) }\end{array}$ & $\begin{array}{l}\text { Public } \\
\text { Bus (4) }\end{array}$ & $\begin{array}{c}\text { Active } \\
\text { Transport (5) }\end{array}$ \\
\hline & & $\mathrm{N}=\mathbf{2 5 9 8}$ & $N=73$ & $N=135$ & $\mathrm{~N}=\mathbf{7 0 7}$ & $N=787$ \\
\hline & Intercept & 14.034 & $0^{\mathrm{b}}$ & 4.718 & 3.639 & 5.347 \\
\hline \multirow{2}{*}{ *Gender } & Male (0) & 0.251 & $0^{\mathrm{b}}$ & -1.334 & -0.256 & 0.658 \\
\hline & Female (1) & $0^{\mathrm{b}}$ & $0^{\mathrm{b}}$ & $0^{\mathrm{b}}$ & $0^{\mathrm{b}}$ & $0^{\mathrm{b}}$ \\
\hline \multirow{2}{*}{$* *$ Citizenship } & Expat (0) & -1.628 & $0^{\mathrm{b}}$ & -1.484 & -1.214 & -1.489 \\
\hline & Local (1) & $0^{\mathrm{b}}$ & $0^{\mathrm{b}}$ & $0^{\mathrm{b}}$ & $0^{\mathrm{b}}$ & $0^{\mathrm{b}}$ \\
\hline \multirow{2}{*}{ *Academic Status } & Student (0) & -1.088 & $0^{\mathrm{b}}$ & -0.37 & 0.204 & 0.781 \\
\hline & Not a student (1) & $0^{\mathrm{b}}$ & $0^{\mathrm{b}}$ & $0^{\mathrm{b}}$ & $0^{\mathrm{b}}$ & $0^{\mathrm{b}}$ \\
\hline \multirow{2}{*}{ *Car Sharing } & No $(0)$ & $0^{\mathrm{b}}$ & $0^{\mathrm{b}}$ & $0^{\mathrm{b}}$ & $0^{\mathrm{b}}$ & $0^{\mathrm{b}}$ \\
\hline & Yes (1) & 6.487 & $0^{\mathrm{b}}$ & 2.943 & 1.415 & -0.45 \\
\hline \multirow{2}{*}{$\begin{array}{c}* * * \text { No of Cars per } \\
\text { Household }\end{array}$} & One or less $(0)$ & 0.059 & $0^{\mathrm{b}}$ & 0.387 & 0.626 & 0.522 \\
\hline & Multiple Cars (1) & $0^{\mathrm{b}}$ & $0^{\mathrm{b}}$ & $0^{\mathrm{b}}$ & $0^{\mathrm{b}}$ & $0^{\mathrm{b}}$ \\
\hline \multirow{2}{*}{ *Car Ownership } & No $(0)$ & $0^{\mathrm{b}}$ & $0^{\mathrm{b}}$ & $0^{\mathrm{b}}$ & $0^{\mathrm{b}}$ & $0^{\mathrm{b}}$ \\
\hline & Yes (1) & 8.229 & $0^{\mathrm{b}}$ & -0.171 & -0.02 & 1.426 \\
\hline \multirow{2}{*}{$\begin{array}{c}* * * \text { Inconvenient Bus } \\
\text { Service }\end{array}$} & No $(0)$ & $0^{\mathrm{b}}$ & $0^{\mathrm{b}}$ & $0^{\mathrm{b}}$ & $0^{\mathrm{b}}$ & $0^{\mathrm{b}}$ \\
\hline & Yes (1) & 3.182 & $0^{\mathrm{b}}$ & 3.273 & 2.531 & 1.654 \\
\hline \multirow{2}{*}{$\begin{array}{c}* * * \text { Harsh Weather } \\
\text { Conditions }\end{array}$} & No $(0)$ & $0^{\mathrm{b}}$ & $0^{\mathrm{b}}$ & $0^{\mathrm{b}}$ & $0^{\mathrm{b}}$ & $0^{\mathrm{b}}$ \\
\hline & Yes (1) & 2.068 & $0^{\mathrm{b}}$ & 4.193 & 2.4 & 2.911 \\
\hline \multirow{2}{*}{$\begin{array}{l}* * * \text { Inadequate } \\
\text { Infrastructure }\end{array}$} & No $(0)$ & $0^{\mathrm{b}}$ & $0^{\mathrm{b}}$ & $0^{\mathrm{b}}$ & $0^{\mathrm{b}}$ & $0^{\mathrm{b}}$ \\
\hline & Yes (1) & 1.293 & $0^{\mathrm{b}}$ & 3.223 & -5.11 & 30.207 \\
\hline *IVTT & Continuous & 0.013 & $0^{\mathrm{b}}$ & 0.028 & 0.037 & -0.077 \\
\hline *OVTT & Continuous & -0.311 & $0^{\mathrm{b}}$ & 0.435 & -0.21 & N.A. \\
\hline *Trip Distance & Continuous & 0.08 & $0^{\mathrm{b}}$ & -0.036 & -0.033 & -0.273 \\
\hline
\end{tabular}

Notes: Taxi is the reference mode, Nagelkerke $R^{2}=0.841, \mathrm{df}=4$, the reference (base) categories are set to zero because it is redundant, *Significant at $1 \%$ level, ** Significant at $5 \%$ level, *** Significant at $10 \%$ level.

\section{Results and discussion}

\subsection{MNL approach results}

Table 4 summarizes the results obtained from analyzing the developed MNL mode-choice models for the five modes of transportation considered in this study. The base (reference) mode, denoted as $0^{\mathrm{b}}$, was chosen to be the taxi because it has the smallest number of observations in order to minimize the number of estimated coefficients for the corresponding utility functions [19]. Not all the variables considered in this study are statistically significant; thus, the model was refined to include only significant factors. Furthermore, the variables reported varying levels of significance. For instance, the number of cars per household is significant at a significance level of $\alpha=10 \%$ whereas the citizenship variable is significant at a significance level of $\alpha=5 \%$; the remaining study variables were significant at a significance level of $\alpha=1 \%$. Table 4 reports the value of the log-likelihood of the null model (i.e., intercept only) and the full model. After the significance of the factors is tested, the model was reduced so the final utility function for traveler $i$ with respect to mode $j$ is defined as the following Eq.6.::

$$
\begin{gathered}
U_{i}(j)=\alpha_{j}+\beta_{1 j} \times \text { Trip Duration }+\beta_{2 j} \times \text { Trip } \\
\text { Distance+ } \\
\beta_{3 j} \times \text { Gender }+\beta_{4 j} \times \text { Citizenship }+\beta_{5 j} \times \\
\text { Status }+\beta_{6 j} \times \text { Car sharing }+\beta_{7 j} \times \\
\text { No. of cars per household }+\beta_{8 j} \times \\
\text { Car ownership }+\beta_{9 j} \times \\
\text { Inconvenient Bus Service }+\beta_{10 j} \times \\
\text { Harsh Weather Conditions }+\beta_{11 j} \times \\
\text { Inadequate Infrastructure }
\end{gathered}
$$

It is concluded that the private cars have the highest utility, followed by active transportation, private and public buses, and taxis respectively. This conclusion is made based on the following: (1) The ordinal nature of the utility functions, where an alternative mode $\mathrm{j}$ will be chosen by a traveler $\mathrm{i}$ over another alternative when it has a higher utility, regardless to the magnitude difference between both modes, and (2) the MNL model results obtained.

Regarding the traveler sociodemographic dichotomous factors, six of these factors showed high significance in affecting the mode choice. Regarding the trip maker's gender, male travelers showed higher positive utility for using active transportation while female users are more likely to use both private and public buses. As clearly shown in Table 4, students are 
the highest category that tends to use active transportation and public transportation in comparison to staff, faculty, and visitors who mostly depend on driving alone their cars. Unsurprisingly, travelers that do not own car tend to use busses and taxis. This is actually related to the number of cars per household factor; that is, the more cars in the household, the higher the odds for travelers to use their own cars. It is interesting to notice that the difference between UAE citizens and non-citizens. The latter group (i.e., expatriates) mostly prefer using taxi and public transportation whereas citizens prefer to use cars to reach the university campus.

An interesting finding is that active transportation is actually the most attractive mode for the following groups: female travelers, students, travelers that do not own a personal private car, travelers with one car or less in their households, and among non-citizens. Car sharing indicated a positive utility for active transportation; that is travelers who share their ride with a family member or colleague usually tend to walk for their internal trips within the SUC campus. The weather condition, lack of adequate infrastructure, and quality of offered bus service affect travelers' mode choice and increase the odds for choosing more sustainable transportation modes.

As expected, factors related to trip cost (namely trip length and duration) affect the mode choice at SUC. The results showed that the longer the trip length and the IVTT required to complete the trip, the more travelers tend to use modes other than active transportation as indicated by the negative utility sign for both factors. There is also a negative utility for choosing private cars and public transit relative to the OVTT. Increasing the times to wait for bus, find parking space for cars, or the walking to final destination or bus stop, clearly decrease the utility for choosing the travel mode.

\subsection{Sensitivity analysis}

The preliminary results indicated that the trip distance affects the travelers' likelihood to choose their transportation mode more than the trip duration. In order to evaluate the magnitude of the utility of trip duration and distance on the mode choice, the probability for using cars, public and private busses, and active transportation were calculated using Eq. 7 while that for the reference mode (i.e. taxi in our study) was calculated using Eq. 8.

$$
\begin{gathered}
P_{r(j=K-1)}=\frac{e^{a j-1+\beta_{j-1} X_{i j}}}{1+\sum_{k=1}^{k-1} e^{a j-1+\beta_{j} X_{i j}}} \\
P_{r(j=k)}=1-\sum_{k=1}^{k-1} P_{j}(j)=\frac{1}{1+\sum_{k=1}^{k-1} e^{\beta_{j} X_{i j}}}
\end{gathered}
$$

The estimated probabilities of the five considered modes were plotted with varying trip duration and distance while keeping the remaining variables as constant. The following assumption was made: An average value for continuous variables was used while the most frequent category was used for the qualitative binary variables. Hence, the following values were utilized: trip average distance $=10.04 \mathrm{~km}$, in-vehicle trip average duration $=26.4$ minutes, out-of-vehicle tip average duration $=16.14$, Gender $=$ Female, Status $=$ Student, Car ownership $=$ Yes, Citizenship $=$ No, Number of cars per household $=$ Multiple, Car sharing $=$ No, Inconvenient bus service $=$ No, Harsh weather conditions $=$ No, and Inadequate Infrastructure $=$ No). A graphical summary of the obtained results of this analysis are illustrated in Figure 2 which shows the probability of choosing the five modes when the in-vehicle trip duration is varied and Figure 3 which shows the probability of choosing the five modes when the trip distance is varied.

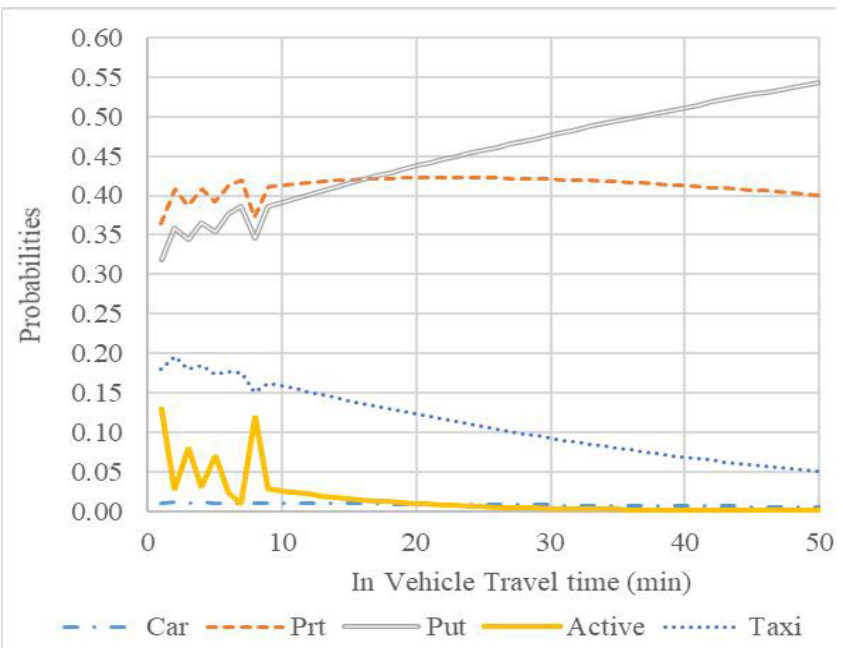

Figure 2: Estimated Probabilities of travelling by different travel modes as a function of in-vehicle travel time.

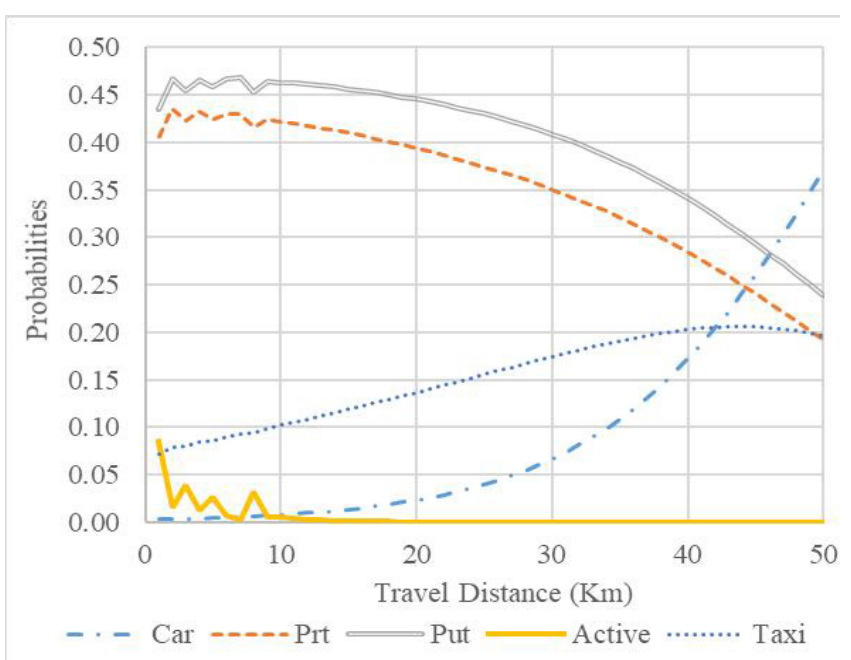

Figure 3: Estimated Probabilities of travelling by different travel modes as a function of Trip Distance.

The probability of choosing active transportation declines with the increase of distance and duration reaching almost $0 \%$ after $10 \mathrm{~km}$ or 30 mins of a trip. This is unsurprising given the fact that traveller's tendency to walk/bike for long distances is the least among all modes. In contrast, the probability of using the car increases with the increase of the trip distance until it becomes the dominant mode at trips that are longer than $45 \mathrm{~km}$ since it offers the shortest travel time. It is important to point out that the trends showed a low utility for the cars over long 
duration trips. This can be justified by the fact that the survey respondents' trips for long distances took less time using cars in contrast to public and private transportation.

It is also observed that both the public and private transportation have the highest utilities among all other travel alternatives. Lastly, there was no noticeable change of the utility of taxi with the change of trip duration due to the fact that only a small proportion of SUC road commuters travel use taxi to travel to campus (a declining utility is observed for the active transportation).

To validate the model developed to predict the travellers' utility of choosing their transportation modes at SUC, the results of the model were compared to those reported by other studies for other university campuses. According to the SUC MNL model, a direct relation between travel time and the mode choice where observed whereas the longer the trip the smaller the utility for the active transportation becomes. This was also indicated by a previous study conducted by Zhou, which showed that with increasing travel time, the drive-alone and public transit become the most dominant modes whereas the active transportation mode becomes more dominant for trips with small duration [3].

Furthermore, this study showed that undergraduate students are the user group that has the highest tendency for choosing active transportation modes. Similar studies, such as a study by Moniruzzaman and Farb, showed comparable results where positive utilities for active transportation were reported for both female users as well as those who have one car or less in their household [11]. In addition, this study clearly showed a negative utility for all transportation modes relative to the car as a driver with the increase of travel distance.

Lastly, our model showed that females, non-citizens, and travellers who do not own a private car, have higher utility for using active transportation and therefore can be targeted for future modal shift solutions. This finding was also stated by Nguyen-Phuoc et al who studied different factors including the travellers' gender, status, car ownership, as well as travel distance and time. The analysis results revealed that females, travellers who do not own a personal car, short travel distances, and short trip duration are all factors with a positive utility for prioritizing active transportation over other modes [20].

\subsection{Suggested polices and solutions}

The following are some solutions to encourage sustainable transportation modes and to reduce daily traffic congestion at SUC: (1) apply parking restrictions to limit the maximum free hours to 2 or 3 hours per day; (2) build a park-and-ride facility close to the campus to allow travellers to park their cars then take the shuttle bus to their final destination; (3) Launch a pay-to-ride bike and scooter to supply students with easy to use and cheap alternatives to travel inside campus; (4) Develop an application where students can register their names for more reliable private and public transport modes that suit their schedules; and (5) Offer mobility on demand private door-to-door services.

\section{Conclusion}

Modelling transportation mode-choice behaviour is an important step to accurately predict future travel demand. Sustainable transportation helps in decreasing the vehicular traffic demand and improving the tendency for using public and active transportation. Though many researchers analysed the modal choice determinants in the MENA region, only a few of these studies focused on university campuses even though university campuses have special travel patterns. This study analysed the most significant determinants that affect travellers' mode choice at Sharjah University City in the UAE. In addition, the study developed discrete mode choice (i.e., multinomial regression) models to examine the mode choice of SUC's travellers. Several sociodemographic factors of the trip makers and trip-specific variables were assessed in terms of their contribution and significance to the final mode choice decision of these travellers.

Although the models developed in this study can not necessarily be generalized to all university campuses; yet they provide insights for other higher-educational institutes when investigating their travel patterns and mode choice determinants. This study has several limitations that hopefully will be overcome in future research. The sample size could be expanded to eliminate any biasness for a specific group of respondents. Furthermore, additional variables believed to affect the mode-choice models at Sharjah University City could be added.

\section{References}

[1] T. Limanond, T. Butsingkorn, and C. Chermkhunthod, "Travel behavior of university students who live on campus: A case study of a rural university in Asia," Transp. Policy, vol. 18, no. 1, pp. 163-171, 2011.

[2] T. Shannon, B. Giles-Corti, T. Pikora, M. Bulsara, T. Shilton, and F. Bull, "Active commuting in a university setting: Assessing commuting habits and potential for modal change," Transp. Policy, vol. 13, no. 3, pp. 240-253, May 2006.

[3] J. Zhou, "Sustainable commute in a car-dominant city: Factors affecting alternative mode choices among university students," Transp. Res. Part A Policy Pract., vol. 46, no. 7, pp. 1013-1029, 2012.

[4] G. Longo, G. Medeossi, and E. Padoano, "Multicriteria analysis to support mobility management at a university campus," in Transportation Research Procedia, 2015, vol. 5, pp. 175-185.

[5] C. Miralles-Guasch and E. Domene, "Sustainable transport challenges in a suburban university: The case of the Autonomous University of Barcelona," Transp. Policy, vol. 17, no. 6, pp. 454-463, 2010.

[6] C. J. . Balsas, "Sustainable transportation planning on college campuses," Transp. Policy, vol. 10, no. 1, pp. 35-49, Jan. 2003.

[7] I. R. Abubakar, F. S. Al-Shihri, and S. M. Ahmed, 
"Students' assessment of campus sustainability at the University of Dammam, Saudi Arabia," Sustainability, vol. 8, no. 1, pp. 1-14, 2016.

[8] A. Aoun, M. Abou-Zeid, I. Kaysi, and C. Myntti, "Reducing parking demand and traffic congestion at the American University of Beirut," Transp. Policy, vol. 25, pp. 52-60, Jan. 2013.

[9] K. Villanueva, B. Giles-Corti, and G. McCormack, "Achieving 10,000 steps: A comparison of public transport users and drivers in a University setting," Prev. Med. (Baltim)., vol. 47, no. 3, pp. 338-341, 2008.

[10] M. Danaf, M. Abou-Zeid, and I. Kaysi, "Modeling travel choices of students at a private, urban university: Insights and policy implications," Case Stud. Transp. Policy, vol. 2, no. 3, pp. 142-152, Dec. 2014.

[11] M. Moniruzzaman and S. Farber, "What drives sustainable student travel? Mode choice determinants in the Greater Toronto Area," Int. $J$. Sustain. Transp., vol. 12, no. 5, pp. 367-379, 2018.

[12] G. Rybarczyk and L. Gallagher, "Measuring the potential for bicycling and walking at a metropolitan commuter university," J. Transp. Geogr., vol. 39, pp. 1-10, 2014.

[13] E. Barata, L. Cruz, and J. P. Ferreira, "Parking at the UC campus: Problems and solutions," Cities, vol. 28, no. 5, pp. 406-413, Oct. 2011.

[14] R. Bridgelall, "Campus parking supply impacts on transportation mode choice," Transp. Plan.
Technol., vol. 37, no. 8, pp. 711-737, 2014.

[15] B. I. Bustillos, J. Shelton, Y.-C. C. Chiu, B. I. Bustillosa, J. Shelton, and Y.-C. C. Chiu, "Urban university campus transportation and parking planning through a dynamic traffic simulation and assignment approach.," Transp. Plan. Technol., vol. 34, no. 2, pp. 177-197, 2011.

[16] L. Dell'Olio, M. Bordagaray, R. Barreda, and A. Ibeas, "A methodology to promote sustainable mobility in college campuses," Transp. Res. Procedia, vol. 3, pp. 838-847, Jan. 2014.

[17] L. Eboli, G. Mazzulla, and A. Salandria, "Sustainable Mobility at a University Campus : Walking Preferences and the Use of Electric Minibus," Int. J. Transp., vol. 1, no. 1, pp. 21-34, 2013

[18] H. Tezcan, "Using parking pricing as a travel demand management tool at a university campus: an example for Istanbul Technical University," Transp. Lett., vol. 4, no. 3, pp. 181-192, 2012.

[19] K. E. Whalen, A. Páez, and J. A. Carrasco, "Mode choice of university students commuting to school and the role of active travel," J. Transp. Geogr., vol. 31, pp. 132-142, Jul. 2013.

[20] D. Q. Nguyen-Phuoc, R. Amoh-Gyimah, A. T. P. Tran, and C. T. Phan, "Mode choice among university students to school in Danang, Vietnam," Travel Behav. Soc., vol. 13, pp. 1-10, Oct. 2018 . 